\title{
Baklofen ved alkoholavhengighet
}

\author{
$\mathrm{GABA}_{B}$-agonisten baklofen, som hovedsakelig benyttes som spasmoly- \\ tikum, er i de senere årene også brukt ved alkoholabstinens og til fore- \\ bygging av tilbakefall ved alkoholavhengighet. Hva er dokumentasjons- \\ grunnlaget for slik behandling?
}

Se også kunnskapsprøve på www.tidsskriftet.no/quiz

\section{Arne Helland}

arne.helland@legemidler.no

Avdeling for klinisk farmakologi

St. Olavs hospital

\section{Jørgen G. Bramness}

Senter for rus og avhengighetsforskning Universitetet i Oslo

og

Avdeling for legemiddelepidemiologi

Nasjonalt folkehelseinstitutt

Baklofen (Lioresal) er en gammaaminosmørsyre (GABA)-analog med selektiv agonistvirkning på G-proteinkoblede $\mathrm{GABA}_{\mathrm{B}}-$ reseptorer. Den eksakte funksjonen til $\mathrm{GABA}_{\mathrm{B}}$-reseptoren er ikke klarlagt, men $\mathrm{GABA}_{\mathrm{B}}$-reseptorer finnes i det sentrale og perifere autonome nervesystemet og har, på samme måte som $\mathrm{GABA}_{\mathrm{A}}$-reseptorkomplekset, en inhibitorisk virkning. Virkningsmekanismen til baklofen er forskjellig fra benzodiazepiner, som virker på $\mathrm{GABA}_{\mathrm{A}}$ reseptorkomplekset. Baklofen har god peroral biotilgjengelighet, maksimal serumkonsentrasjon etter ca. to timer og en terminal halveringstid på 2-4 timer. Over $80 \%$ skilles ut uforandret via nyrene (1).

Baklofen har vært markedsført siden 1972 mot muskelspasmer, for eksempel ved multippel sklerose og cerebral parese, og brukes vanligvis i doser på $15-80 \mathrm{mg}$ per døgn. Andre bruksområder har bl.a. vært blærefunksjonsforstyrrelser hos tverrsnittslammede, trigeminusnevralgi og andre former for nevropatisk smerte, clusterhodepine og migrene, kronisk hikke og gastroøsofageal reflukssykdom. Baklofen gis oftest peroralt, men kan også administreres intratekalt.

Sentrale elementer i alkoholavhengighet er alkoholabstinenser, som kan vare noen døgn etter drikkestans, og drikketrang (craving), som kan vedvare $\mathrm{i}$ flere år etter opphør av alkoholinntak. Drikketrang er en viktig årsak til tilbakefall, og dermed også viktig å redusere for å opprettholde avholdenhet (2). Ulike farmakologiske tilnærminger med forskjel- lige virkemekanismer har vært forsøkt, inkludert disulfiram (Antabus), akamprosat (Campral) og naltrekson (Revia) (1). Effekten av disse medikamentene er dessverre ofte utilstrekkelig, og mange pasienter får tilbakefall.

Den fransk-amerikanske legen Olivier Ameisen hadde $\mathrm{i}$ årevis hatt mange opphold ved avrusningsklinikker og deltatt aktivt i Anonyme Alkoholikere. Ved avslutning av rehabiliteringsopphold opplevde han stadig tilbakefall, selv ved bruk av medikamenter som naltrekson, akamprosat og disulfiram, og også til en viss grad ved vanlige doser baklofen. Da han prøvde høye doser baklofen $(270 \mathrm{mg} / \mathrm{dag})$, forsvant hans alkoholsug helt (3). Boken han skrev på bakgrunn av sine erfaringer, ble en mye omtalt bestselger (fig 1) (4). Hans observasjoner ble blant annet hyllet av den franske nobelprisvinneren i medisin fra 1980, Jean Dausset, som uttalte at Ameisen endelig hadde funnet en kur mot alkoholisme.

De seneste årene er det publisert flere kliniske studier av baklofen til alkoholavhengige. Hensikten med denne artikkelen er å gjennomgå dokumentasjonen for bruk av baklofen ved alkoholabstinens og alkoholavhengighet og å foreslå hvordan medikamentet eventuelt kan brukes ved disse indikasjonene.

\section{Materiale og metode}

Artikkelen bygger på et ikke-systematisk litteratursøk i PubMed for perioden 1980-2011. Det ble i tillegg til søketermen «baclofen» søkt med termene «alcohol» eller «drug» i kombinasjon med termene «dependence», «addiction», «craving», «withdrawal» og «abstinence».

\section{Virkemåte}

Antakelig er de dopaminerge mesolimbiske motivasjonsbanene sentrale for etanols avhengighetsskapende effekt. $\mathrm{GABA}_{\mathrm{B}}$-reseptorer finnes på dopaminerge nevroner $\mathrm{i}$ det ventrale tegmentale området (VTA), utgangspunktet for de mesolimbiske motivasjonsbanene. $\mathrm{GABA}_{\mathrm{B}}$-agonisme vil kunne hemme den etanolmedierte dopaminfrisettingen i det mesolimbiske systemet, og dermed svekke responsen på alkohol og alkoholrelaterte stimuli som kan gi drikketrang hos alkoholavhengige.

Ved alkoholabstinens antas det at presynaptisk $\mathrm{GABA}_{\mathrm{B}}$-agonisme på glutamaterge nevroner i samme område kan redusere glutamaterg overaktivitet som er assosiert med alkoholabstinenssymptomer (5).

\section{Baklofen ved alkoholabstinens}

De fleste alkoholabstinenser er milde og skal ikke behandles medikamentelt. I Norge er man vanligvis tilbakeholden med bruk av benzodiazepiner eller andre GABA-erge midler til ren symptomatisk behandling av alkoholabstinenser på grunn av disse midlenes misbruks- og intoksikasjonsfare. Benzodiazepiner, som har den mest solide dokumentasjon for effekt, forbeholdes gjerne de mest alvorlige tilfellene av alkoholabstinens, samt truende eller manifeste komplikasjoner i form av alkoholutløste kramper eller delirium (6). Gitt problemene med misbruk, avhengighet og psykomotoriske bivirkninger som hefter ved benzodiazepiner, er det viktig å finne frem til effektive alternativer til disse midlene $\mathrm{i}$ behandlingen av alkoholabstinens.

Både dyrestudier, kasusrapporter og små kliniske studier på mennesker har vist at baklofen kan redusere abstinenssymptomer som angst, tremor og krampetendens (1). Baklofen er sammenliknet med diazepam i en enkelblindet. randomisert studie med 37 deltakere (7). Både i diazepam- og baklofengruppen ble det funnet sammenliknbar reduksjon av tremor, svetting, angst og agitasjon, men effekten av diazepam inntrådte noe raskere. Cochrane-samarbeidet fant i sin litteraturgjennomgang at kun denne studien var god nok til å bli inkludert, og konklu-

\section{Hovedbudskap}

- Baklofen er en $\mathrm{GABA}_{B}$-agonist uten kjent misbrukspotensial som er undersøkt ved alkoholrelaterte tilstander

- Dokumentasjonen for bruk ved alkoholabstinenser er utilstrekkelig

- Baklofen kan være et alternativ til disulfiram eller akamprosat som forebyggende behandling mot tilbakefall ved alkoholavhengighet 
derte med at kunnskapsgrunnlaget er for lite til å kunne anbefale baklofen ved alkoholabstinens (5).

\section{Baklofen for å opprettholde alkoholavholdenhet}

Dyrestudier og åpne humanstudier har indikert at baklofen kan bidra til å opprettholde avholdenhet og redusere drikketrang (1) Det er gjennomført tre randomiserte, placebokontrollerte, blindede studier av baklofen i doser på $10 \mathrm{mg}$ tre ganger daglig. En studie over fire uker av 39 mannlige polikliniske pasienter med alkoholavhengighet viste mindre bruk av alkohol, mindre tvangsmessig forhold til drikking og marginalt mindre angst i baklofengruppen (8). Resultatene ble bekreftet i en større studie over 12 uker med 84 deltakere med levercirrhose, som viste signifikant reduksjon av drikketrang, høyere grad av avholdenhet (71\% mot 29\%) og lavere risiko for tilbakefall (19\% mot $45 \%)$ i baklofengruppen. Færre droppet ut av studien i baklofengruppen enn i placebogruppen, men forskjellen var ikke signifikant (9). Begge studiene var italienske. En tilsvarende 12 ukers studie fra USA med 80 deltakere uten cirrhose viste derimot ingen forskjell i drikketrang, drikkeepisoder eller grad av avholdenhet (10). Diskrepansen er forsøkt forklart med at baklofen skulle ha en bedre effekt blant de tyngre alkoholmisbrukerne som var inkludert $\mathrm{i}$ de italienske studiene, bl.a. begrunnet $i$ at deltakerne her var rekruttert fra behandlingsinstitusjoner, mens de amerikanske deltakerne var rekruttert gjennom avisannonser (1).

Den italienske gruppen har senere gjennomført en mindre studie med tre grupper à 14 alkoholavhengige personer, som fikk henholdsvis placebo, baklofen $30 \mathrm{mg} / \mathrm{dag}$ og baklofen $60 \mathrm{mg} / \mathrm{dag}$. Det ble funnet en doserespons-effekt på antall alkoholenheter konsumert per dag, med færrest i gruppen som fikk den høyeste baklofendosen (11). Dette var imidlertid en post hoc-analyse, og det ble ikke funnet statistisk signifikante forskjeller mellom gruppene på de forhåndsdefinerte utfallsvariablene i studien. Resultatene kan derfor ikke tillegges stor vekt.

Ved siden av Olivier Ameisens selvbiografiske bok og artikkel $(3,4)$, er det publisert to kasuistikker hvor man ved høy dosering av baklofen (140-270 mg/døgn) oppnådde fullstendig undertrykking av alkoholsug (1). En større randomisert, kontrollert studie med doser opptil 150-200 mg/døgn er underveis takket være en velhavende og filantropisk innstilt tidligere alkoholiker, som ble tørrlagt ved hjelp av baklofen og donerte et betydelig beløp til videre utprøving (12).

\section{Bivirkninger}

Baklofen har vært brukt i flere tiår og er ansett for å være et sikkert og godt tolerert medikament mot spastisitet. I de omtalte alkoholstudiene ble det ikke rapportert alvorlige bivirkninger, herunder ruseffekt eller problemer ved seponering. Imidlertid foreligger det rapporter om abstinenssyndrom ved bråseponering av langvarig baklofenbehandling.

Vanlige bivirkninger er tretthet, moderat blodtrykksfall og svimmelhet. Depresjon, eufori, forvirringstilstander og hallusinasjoner er også beskrevet. Det er sett en viss økning av kramperisikoen, noe som kan tilsi forsiktighet hos pasienter med senket krampeterskel, for eksempel ved akutt alkoholabstinens. Medikamentet synes ellers å være relativt trygt hos alkoholavhengige, inklusive pasienter med alkoholisk levercirrhose, selv om en viss additiv sedativ effekt kan forventes ved samtidig inntak av alkohol $(1,9)$.

\section{Anbefalinger for bruk}

Baklofen er per i dag ikke godkjent i Norge til bruk ved alkoholabstinens eller alkoholavhengighet. Bruk utenfor indikasjon er fullt lovlig, men medfører økt ansvar og juridisk risiko for den enkelte forskriver.

Det er foreløpig utilstrekkelig dokumentasjon for å kunne anbefale baklofen ved indikasjonen akutt alkoholabstinens. Andre midler som benzodiazepiner, valproat og karbamazepin har en etablert plass i behandlingen, er bedre dokumentert og bør foretrekkes.

Disulfiram og akamprosat er godkjente preparater til opprettholdelse av alkoholavhold i Norge. For pasienter med utilstrekkelig effekt av disse midlene, eller som av andre grunner ikke kan benytte disse, kan baklofen være et aktuelt alternativ. I kliniske studier av baklofen til opprettholdelse av alkoholavhold har den undersøkte døgndosen hovedsakelig vært $30 \mathrm{mg}$ fordelt på tre doser - men i én studie har man benyttet døgndoser på opptil $60 \mathrm{mg}$. De kliniske studiene peker i retning av at pasienter med tyngre alkoholmisbruk, især ved komorbid angstlidelse, kan være velegnet for baklofenbehandling. Preparatet er funnet å være trygt, også hos pasienter med alkoholisk levercirrhose, som utgjør en gruppe med særlig behov for totalavhold fra alkohol. Det er kun anekdotiske holdepunkter for effekt av mer høydosert behandling, og dette kan derfor ikke anbefales inntil det foreligger mer systematiske undersøkelser.

\section{Jørgen G. Bramness (f. 1962)}

er professor og forskningsdirektør ved Senter for rus og avhengighetsforskning ved Universitetet i Oslo og seniorforsker ved Avdeling for legemiddelepidemiologi ved Nasjonalt folkehelseinstitutt. Han har en bakgrunn innen psykiatri og farmakologi.

Ingen oppgitte interessekonflikter.

\section{Arne Helland (f. 1977)}

er cand.med. og spesialist i klinisk farmakologi. Han jobber som konstituert overlege ved Avdeling for klinisk farmakologi, St. Olavs hospital. Ingen oppgitte interessekonflikter.

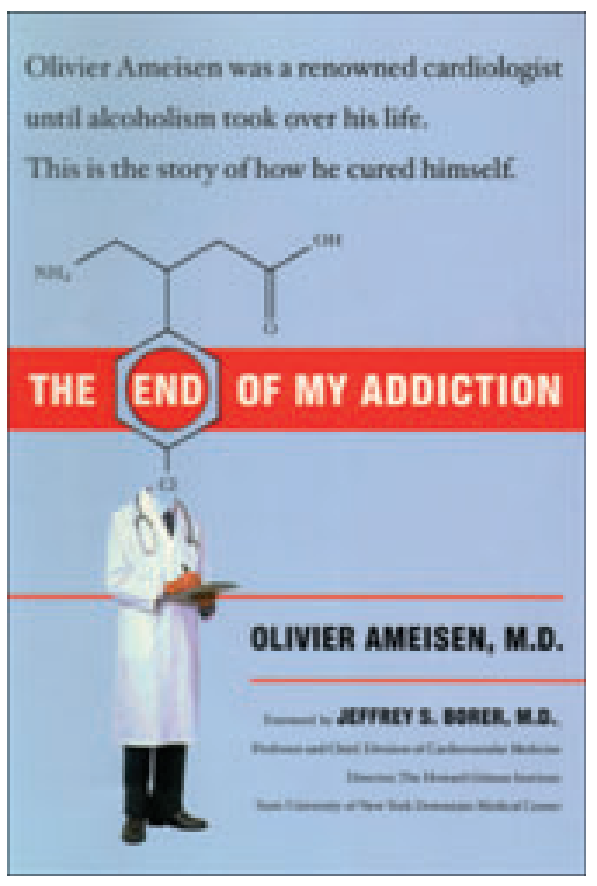

Figur 1 Faksimile av legen Olivier Ameisens bestselger, der han forteller om hvordan han ved hjelp av høye doser baklofen ble kurert for sitt alkoholsug (3)

\section{Litteratur}

1. Leggio L, Garbutt JC, Addolorato G. Effectiveness and safety of baclofen in the treatment of alcohol dependent patients. CNS Neurol Disord Drug Targets 2010; 9: 33-44

2. Mørland J. Biologiske virkningsmekanismer og noen kliniske effekter av alkohol. Tidsskr Nor Lægeforen 2003; 123: 180-4.

3. Ameisen 0 . The end of my addiction. Loughton (UK): Piatus, 2009.

4. Ameisen O. Complete and prolonged suppression of symptoms and consequences of alcohol-dependence using high-dose baclofen: a self-case report of a physician. Alcohol Alcohol 2005; 40: 147-50.

5. Liu J, Wang L. Baclofen for alcohol withdrawal. Cochrane Database Syst Rev 2011; nr. 1 : CD008502.

6. Helland A, Skjøtskift S. Medikamentell behandling av alkoholabstinens. Tidsskr Nor Legeforen 2008 128: $1182-4$

7. Addolorato G, Leggio L, Abenavoli L et al. Baclofen in the treatment of alcohol withdrawal syndrome: a comparative study vs diazepam. Am J Med 2006 119: 276 e $13-8$

8. Addolorato G, Caputo F, Capristo E et al. Baclofen efficacy in reducing alcohol craving and intake: a preliminary double-blind randomized controlled study. Alcohol Alcohol 2002; 37: 504-8.

9. Addolorato G, Leggio L, Ferrulli A et al. Effectiveness and safety of baclofen for maintenance of alcohol abstinence in alcohol-dependent patients with liver cirrhosis: randomised, double-blind controlled study. Lancet 2007; 370: 1915-22.

10. Garbutt JC, Kampov-Polevoy AB, Gallop R et al. Efficacy and safety of baclofen for alcohol dependence: a randomized, double-blind, placebo-controlled trial. Alcohol Clin Exp Res 2010: 34 1849-57.

11. Addolorato G, Leggio L, Ferrulli A et al. Doseresponse effect of baclofen in reducing daily alcohol intake in alcohol dependence: secondary analysis of a randomized, double-blind, placebo-controlled trial. Alcohol Alcohol 2011; 46: 312-7.

12. Enserink M. Addiction research. Anonymous alcoholic bankrolls trial of controversial therapy. Science 2011: 332: 653 